\title{
Pengaruh Kompos TKKS, Jerami Padi dan Pupuk NPK terhadap Pertumbuhan dan Produksi Tanaman Cabai (Capsicum annuum L.)
}

\section{The Effect of Compost TKKS, Rice Straw and NPK Fertilizer on the Growth and Production of Chili Plant (Capsicum annuum L.)}

\author{
Hapsoh $^{1 *}$, Zulfa Leyna ${ }^{1}$, dan Murniati ${ }^{1}$
}

Diterima 22 November 2018/Disetujui 04 Februari 2019

\begin{abstract}
This study aims to determine the effect of compost and NPK fertilizer on the growth and production of chili pepper and get the best combination of treatments. This research was conducted at the University of Experimental Riau Agriculture Faculty of Garden from September 2017 to February 2018. This study used a randomized block design (RBD). The first factor was compost consisting of 3 levels: without compost, compost TKKS and rice straw compost. The second factor is

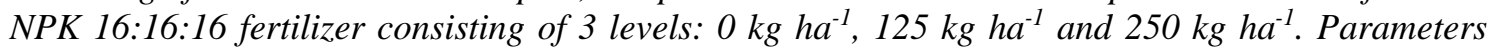
observed were initial soil analysis, plant height, dichotomous height, crown width, flowering age, harvest age, fruit length, number of fruits per plant, fruit weight per plant and fruit weight per plot. Based on the results of the study it was found that the best treatment was application of rice straw compost 5 ton $\mathrm{ha}^{-1}$ and $125 \mathrm{~kg} \mathrm{ha}^{-1} \mathrm{NPK}$ fertilizer (1/2 recommended dosage).
\end{abstract}

Keywords: C-organic, Dichotomous height, Fruit weight, Inceptisol

\begin{abstract}
ABSTRAK
Percobaan ini bertujuan untuk mengetahui pengaruh kompos dan pupuk NPK terhadap pertumbuhan dan produksi tanaman cabai dan mendapatkan kombinasi perlakuan yang terbaik. Percobaan ini dilaksanakan di Kebun Percobaan Fakultas Pertanian Universitas Riau pada bulan September 2017 sampai Februari 2018. Percobaan ini menggunakan rancangan acak kelompok (RAK). Faktor pertama adalah kompos terdiri dari 3 taraf: tanpa kompos, kompos dari Tanda Kosong Kelapa Sawit (TKKS) dan kompos dari jerami padi. Faktor kedua adalah pupuk NPK 16:16:16 terdiri dari 3 taraf: $0 \mathrm{~kg} \mathrm{ha}^{-1}, 125 \mathrm{~kg} \mathrm{ha}^{-1}$ dan $250 \mathrm{~kg} \mathrm{ha}^{-1}$. Parameter yang diamati yaitu analisis tanah awal, tinggi tanaman, tinggi dikotomus, lebar tajuk, umur berbunga, umur panen, panjang buah, jumlah buah per tanaman, bobot buah per tanaman dan bobot buah per plot. Berdasarkan hasil penelitian didapatkan perlakuan terbaik yaitu pemberian kompos jerami padi 5 ton $\mathrm{ha}^{-1}$ dan pupuk NPK $125 \mathrm{~kg} \mathrm{ha}^{-1}$ (1/2 dosis anjuran).
\end{abstract}

Kata kunci: Bobot buah, C-organik, Inseptisol, Tinggi dikotomus

\section{PENDAHULUAN}

Cabai merah (Capsicum annuum L.) merupakan salah satu komoditas hortikultura dari kelompok sayuran penting di Indonesia, karena memiliki nilai ekonomi yang tinggi dan bermanfaat untuk kesehatan manusia. Cabai mengandung protein, lemak, karbohidrat, kalsium $(\mathrm{Ca})$, fosfor $(\mathrm{P})$, besi $(\mathrm{Fe})$, vitaminvitamin dan mengandung senyawa-senyawa alkaloid, seperti capsaicin, flavonoid dan minyak esensial. Capsaicin merupakan zat atau senyawa yang berfungsi dalam

${ }^{1}$ Jurusan Agroteknologi, Fakultas Pertanian, Universitas Riau E-mail : hapsohdin@yahoo.co.id (*Penulis korespondensi) 
mengendalikan penyakit kanker dan juga yang menimbulkan rasa pedas pada cabai.

Produksi cabai merah di Provinsi Riau tahun 2014 sebesar 9355 ton dengan luas panen 1878 ha dan produktivitas 4.98 ton ha $^{-1}$. Produksi dan produktivitas cabai merah di Provinsi Riau ini masih tergolong rendah jika dibandingkan dengan provinsi lain, seperti Sumatera Barat yang mencapai 59 390 ton dengan luas panen 7578 ha dan produktivitas 7.83 ton ha-1 (BPS, 2015).

Rendahnya produksi dan produktivitas cabai merah di Provinsi Riau disebabkan oleh pengembangan lahan yang kurang, rendahnya tingkat kesuburan tanah, serangan hama dan penyakit serta kekeringan. Rendahnya tingkat kesuburan tanah dapat diatasi dengan penambahan bahan organik ke dalam tanah. Penambahan bahan organik dapat memperbaiki sifat fisik, biologi dan kimia tanah. Sumber bahan organik dapat berupa kompos yang berasal dari sisa panen (seperti jerami padi, tandan kosong kelapa sawit (TKKS), brangkasan, tongkol jagung dan tebu), pupuk hijau, pupuk kandang, limbah ternak, limbah industri yang menggunakan bahan pertanian dan limbah kota (sampah).

Sampah pasar dan sampah restoran umumnya bersifat biodegradable, yaitu mudah terurai menjadi senyawa-senyawa yang lebih sederhana oleh mikrob, sehingga dapat dimanfaatkan sebagai pupuk organik dengan dikomposkan. Limbah pertanian sebagian besar merupakan limbah lignoselulosa yang menghasilkan karbon dan energi yang digunakan oleh mikrob di dalam kompos. Kombinasi penggunaan sampah pasar dan sampah restoran dengan jerami padi dan tandan kosong kelapa sawit (TKKS) dapat membantu proses penguraian bahan organik lebih cepat dalam pengomposan. Hasil percobaan Yusuf (2014) menunjukkan bahwa kompos jerami padi yang ditambah dengan sampah pasar memenuhi standar kualitas kompos Indonesia SNI 19-70302004 dengan sifat fisik kompos berwarna hitam tanah, C/N rasio $19.50, \mathrm{pH} 7.42, \mathrm{C}-$ organik 21.84 , bahan organik $37.65 \%$ dan kandungan unsur hara makro $\mathrm{N} 1.12 \%, \mathrm{P}$ $0.23 \%$ dan K $0.60 \%$.

Kandungan unsur hara, tingkat kelarutan, dan laju pelepasan pupuk organik umumnya lebih rendah dibandingkan pupuk anorganik. Kandungan unsur hara di dalam pupuk organik yang tersedia sangat bervariasi dan tidak dalam bentuk yang tersedia secara langsung bagi tanaman. Unsur hara di dalam pupuk organik relatif lebih lama untuk dapat diserap oleh tanaman, sehingga pemberian pupuk organik perlu diimbangi dengan pupuk anorganik diantaranya pupuk majemuk NPK.

Tujuan penelitian ini adalah untuk mengetahui pengaruh interaksi kompos TKKS, jerami padi dan pupuk NPK terhadap pertumbuhan dan produksi tanaman cabai serta mendapatkan kombinasi perlakuan yang terbaik.

\section{BAHAN DAN METODE}

Percobaan ini telah dilaksanakan di Kebun Percobaan Unit Pelayanan Teknis (UPT) Fakultas Pertanian Universitas Riau. Percobaan ini dilaksanakan dari bulan September 2017 sampai Februari 2018.

Bahan yang digunakan dalam penelitian terdiri atas bibit cabai varietas lokal, kompos TKKS (Tandan Kosong Kelapa Sawit + sampah restoran + decomposer), kompos jerami padi (jerami padi + sampah pasar + decomposer), decomposer menggunakan mikroorganisme selulolitik (MOS) dari bakteri kulit durian (BKD), pupuk NPK Mutiara (16:16:16), mulsa plastik hitam perak (MPHP), Furadan, Dithane M-45, dan Curacron 500 EC.

Alat yang digunakan dalam percobaan ini adalah meteran untuk mengukur tinggi dikotomus, tinggi tanaman dan lebar tajuk, tali dan penggaris untuk mengukur panjang buah, timbangan digital untuk mengukur bobot buah per tanaman dan bobot buah per plot.

Percobaan ini dilaksanakan dalam bentuk faktorial $3 \times 3$ disusun menurut rancangan acak kelompok (RAK). Faktor pertama adalah kompos $(\mathrm{K})$ terdiri atas 3 taraf: $K_{1}=$ Tanpa kompos $\left(0\right.$ ton $\left.h^{-1}\right), K_{2}=$ Kompos TKKS $\left(5\right.$ ton ha $\left.{ }^{-1}\right)$ dan $\mathrm{K}_{3}=$ Kompos jerami padi $\left(5\right.$ ton $\left.\mathrm{ha}^{-1}\right)$. Faktor kedua adalah pupuk NPK $(\mathrm{N})$ terdiri atas 3 taraf : $\mathrm{N}_{1}=$ Pupuk NPK $0 \mathrm{~kg} \mathrm{ha}^{-1}$ (0 dosis anjuran), $\mathrm{N}_{2}=$ Pupuk NPK $125 \mathrm{~kg} \mathrm{ha}^{-1}$ (1/2 dosis anjuran) dan $\mathrm{N}_{3}=$ Pupuk NPK $250 \mathrm{~kg} \mathrm{ha}^{-1}$ (dosis anjuran). Dari kedua faktor, terdapat 9 
kombinasi perlakuan. Masing-masing kombinasi diulang $3 \mathrm{kali}$, sehingga terdapat 27 unit percobaan. Setiap unit percobaan terdiri dari 14 tanaman, 5 diantaranya dijadikan tanaman sampel. Data yang diperoleh dari penelitian ini dianalisis secara statistik dengan analisis ragam menggunakan SAS System Version 9.12. Hasil sidik ragam dilanjutkan dengan uji jarak berganda Duncan (DMRT) pada taraf $\alpha=5 \%$.

\section{HASIL DAN PEMBAHASAN}

\section{Hasil Analisis Tanah Awal}

Hasil analisis tanah awal penelitian menunjukkan bahwa tanah yang digunakan dalam percobaan ini sebelum diberi perlakuan termasuk ke dalam tanah yang sangat masam dengan $\mathrm{pH} \mathrm{H}_{2} \mathrm{O}$ berkisar 4.48. Dilihat dari nilai $\mathrm{pH}$ tanah, maka tanah ini dapat digolongkan ke dalam tanah mineral masam, pH tanah yang sangat masam membuat reaksi-reaksi kimia yang terjadi di dalam tanah berjalan lambat sehingga dapat mengganggu atau menghambat pertumbuhan tanaman yang dibudidayakan. Hasil analisis tanah awal sebelum diberi perlakuan disajikan pada Tabel 1.

\section{Hasil Analisis Statistik dan Pertumbuhan Tanaman Cabai yang Diberi Kompos dan Pupuk NPK}

Hasil analisis statistik pertumbuhan tanaman cabai merah dapat dilihat pada Tabel 2. Tabel 2 menunjukkan bahwa pemberian kompos berpengaruh nyata terhadap tinggi tanaman, lebar tajuk, dan umur panen tanaman cabai. Pemberian pupuk NPK berpengaruh nyata terhadap tinggi tanaman, tinggi dikotomus, lebar tajuk, dan umur berbunga. Sedangkan pemberian kompos dan pupuk NPK tidak menunjukkan pengaruh nyata terhadap tinggi tanaman, tinggi dikotomus, lebar tajuk, umur berbunga, dan umur panen tanaman cabai. Peningkatan pertumbuhan tanaman cabai dapat dilihat pada Tabel 3 .

Tabel 1. Hasil analisis tanah awal sebelum diberi perlakuan

\begin{tabular}{|c|c|c|}
\hline Sifat Tanah & Hasil Analisis & Kriteria*) $^{*}$ \\
\hline $\mathrm{pH}(1: 1) \mathrm{H}_{2} \mathrm{O}$ & 4.48 & Sangat masam \\
\hline C-Organik (\%) & 2.97 & Sedang \\
\hline N-Total (\%) & 0.26 & Sedang \\
\hline P-Total (mg $100 \mathrm{~g}^{-1}$ ) & 61.63 & Sangat tinggi \\
\hline K-Total (mg $\left.100 \mathrm{~g}^{-1}\right)$ & 22.84 & Sedang \\
\hline Al-dd $(\mathrm{cmol}(+) / \mathrm{kg})^{*}$ & 0.57 & - \\
\hline Kejenuhan $\mathrm{Al}(\%)^{*}$ & 13.18 & Rendah \\
\hline
\end{tabular}

Tabel 2. Hasil analisis statistik pertumbuhan tanaman cabai

\begin{tabular}{lccccc}
\hline Perlakuan & $\begin{array}{c}\text { Tinggi } \\
\text { Tanaman }\end{array}$ & $\begin{array}{c}\text { Tinggi } \\
\text { Dikotomus }\end{array}$ & $\begin{array}{c}\text { Lebar } \\
\text { Tajuk }\end{array}$ & $\begin{array}{c}\text { Umur } \\
\text { Berbunga }\end{array}$ & $\begin{array}{c}\text { Umur } \\
\text { Panen }\end{array}$ \\
\hline Kompos & & & & & \\
$\quad$ F. hitung & $42.64^{*}$ & $2.66^{\mathrm{ns}}$ & $8.52^{*}$ & $2.81^{\mathrm{ns}}$ & $13.28^{*}$ \\
$\quad$ F. tabel & 3.63 & 3.63 & 3.63 & 3.63 & 3.63 \\
NPK & & & & & \\
$\quad$ F. hitung & $19.24^{*}$ & $5.17^{*}$ & $5.48^{*}$ & $5.33^{*}$ & $1.50^{\mathrm{ns}}$ \\
$\quad \begin{array}{l}\text { F. tabel } \\
\text { Kompos* NPK }\end{array}$ & 3.63 & 3.63 & 3.63 & 3.63 & 3.63 \\
$\quad$ F. hitung & $2.73^{\mathrm{ns}}$ & $0.24^{\mathrm{ns}}$ & $0.34^{\mathrm{ns}}$ & $0.37^{\mathrm{ns}}$ & $0.11^{\mathrm{ns}}$ \\
$\quad$ F. tabel & 3.01 & 3.01 & 3.01 & 3.01 & 3.01 \\
\hline
\end{tabular}

Keterangan: *= nyata; ns=tidak nyata 
Tabel 3. Pertumbuhan tanaman cabai yang diberi kompos dan pupuk NPK

\begin{tabular}{llllll}
\hline \multicolumn{1}{c}{ Perlakuan } & $\begin{array}{c}\text { Tinggi } \\
\text { Tanaman }\end{array}$ & $\begin{array}{c}\text { Tinggi } \\
\text { Dikotomus }\end{array}$ & $\begin{array}{c}\text { Lebar } \\
\text { Tajuk }\end{array}$ & $\begin{array}{c}\text { Umur } \\
\text { Berbunga }\end{array}$ & $\begin{array}{c}\text { Umur } \\
\text { Panen }\end{array}$ \\
\hline Tanpa kompos + NPK 0 kg ha-1 & $69.60 \mathrm{e}$ & $22.23 \mathrm{~b}$ & $75.70 \mathrm{~d}$ & $26.67 \mathrm{~b}$ & $82.67 \mathrm{~d}$ \\
Tanpa kompos + NPK 125 kg ha-1 & $70.07 \mathrm{e}$ & $24.43 \mathrm{ab}$ & $77.53 \mathrm{~cd}$ & $26.00 \mathrm{ab}$ & $81.67 \mathrm{~cd}$ \\
Tanpa kompos + NPK 250 kg ha-1 & $70.73 \mathrm{de}$ & $24.83 \mathrm{ab}$ & $81.12 \mathrm{bcd}$ & $25.00 \mathrm{ab}$ & $80.33 \mathrm{bcd}$ \\
Kompos TKKS + NPK 0 kg ha-1 & $69.87 \mathrm{e}$ & $23.37 \mathrm{ab}$ & $77.07 \mathrm{~cd}$ & $25.33 \mathrm{ab}$ & $76.67 \mathrm{abc}$ \\
Kompos TKKS + NPK 125 kg ha-1 & $72.00 \mathrm{de}$ & $24.33 \mathrm{ab}$ & $83.50 \mathrm{bcd}$ & $25.00 \mathrm{ab}$ & $76.33 \mathrm{abc}$ \\
Kompos TKKS + NPK 250 kg ha-1 & $75.20 \mathrm{bc}$ & $24.67 \mathrm{ab}$ & $90.18 \mathrm{ab}$ & $24.67 \mathrm{a}$ & $74.00 \mathrm{a}$ \\
Kompos Jerami + NPK 0 kg ha-1 & $73.07 \mathrm{~cd}$ & $24.17 \mathrm{ab}$ & $85.93 \mathrm{abcd}$ & $26.00 \mathrm{ab}$ & $75.33 \mathrm{ab}$ \\
Kompos Jerami + NPK 125 kg ha-1 & $77.40 \mathrm{ab}$ & $25.47 \mathrm{a}$ & $88.42 \mathrm{abc}$ & $25.00 \mathrm{ab}$ & $76.33 \mathrm{abc}$ \\
Kompos Jerami + NPK 250 kg ha-1 & $79.07 \mathrm{a}$ & $25.93 \mathrm{a}$ & $96.05 \mathrm{a}$ & $24.33 \mathrm{a}$ & $74.00 \mathrm{a}$ \\
\hline
\end{tabular}

Keterangan: Angka-angka yang diikuti oleh huruf kecil pada baris yang sama menunjukkan tidak berbeda nyata menurut uji jarak berganda Duncan pada taraf 5\%.

Tabel 3 menunjukkan pemberian kompos jerami padi dan pupuk NPK $250 \mathrm{~kg} \mathrm{ha}^{-1}$ dapat meningkatkan tinggi tanaman cabai, tidak berbeda nyata dengan pemberian kompos jerami padi dan pupuk NPK $125 \mathrm{~kg} \mathrm{ha}^{-1}$, namun nyata lebih baik dibandingkan dengan kombinasi perlakuan lainnya. Hal ini karena nilai C-organik kompos jerami padi $(25.58 \%)$ sudah sesuai dengan standar SNI kompos yaitu berkisar 9.8-32\% yang dapat meningkatkan kandungan C-organik pada tanah penelitian sehingga ketersediaan unsur hara menjadi lebih baik, dengan adanya penambahan pupuk NPK $250 \mathrm{~kg} \mathrm{ha}^{-1}$ unsur hara lebih cepat tersedia dan dapat diserap oleh tanaman. Arifiati et al. (2017) menyatakan bahwa peningkatan C-organik tanah akibat adanya pelepasan dari kompos. Perbedaan nilai bahan organik karena adanya pengaruh dalam pemberian kompos dan proses dekomposisi oleh mikrob tanah. Di dalam tanah mikrob tanah menggunakan bahan organik sebagai sumber energi dan perkembangan mikrob.

Pemberian kompos jerami padi dan pupuk NPK $125 \mathrm{~kg} \mathrm{ha}^{-1}$ serta pemberian kompos jerami padi dan pupuk NPK $250 \mathrm{~kg}$ $\mathrm{ha}^{-1}$ memberikan nilai rerata tinggi dikotomus tanaman cabai lebih tinggi secara kuantitatif, berbeda nyata dengan perlakuan tanpa kompos dan tanpa NPK, namun tidak berbeda nyata dengan kombinasi perlakuan lainnya (Tabel 3). Hasil penelitian Sugestiadi et al. (2014), tinggi dikotomus berkorelasi positif terhadap tinggi tanaman cabai. Tinggi tanaman sangat dipengaruhi oleh unsur hara nitrogen $(\mathrm{N})$, apabila unsur hara $\mathrm{N}$ terpenuhi maka pertumbuhan tinggi tanaman dapat mencapai maksimal. Hasil penelitian Hapsoh et al. (2017) menunjukkan bahwa perlakuan kompos jerami padi $25 \mathrm{~g}$ ditambah NPK $12.5 \mathrm{~g}$ menghasilkan tinggi tanaman cabai tertinggi yaitu $60.3 \mathrm{~cm}$ dibandingkan dengan perlakuan lainnya yaitu tanpa kompos dan NPK $12.5 \mathrm{~g}$ dengan tinggi $42.96 \mathrm{~cm}$.

Lebar tajuk tanaman cabai cenderung meningkat dengan pemberian kompos yang sama dan peningkatan dosis NPK (Tabel 3). Hasil-hasil tersebut dapat disebabkan karena pemberian kompos dapat meningkatkan ketersediaan $\mathrm{N}$ yang merupakan salah satu unsur utama yang memengaruhi pertumbuhan tanaman (Antil et al., 2011). Hasil penelitian Subhan et al. (2009), setiap unsur hara yang terkandung di dalam pupuk NPK majemuk mendukung berbagai proses metabolisme sel seperti fotosintesis dan respirasi sehingga dapat meningkatkan hasil buah tomat.

Tanaman cabai yang diberi pupuk (kompos pupuk NPK maupun kombinasinya) umur berbunganya relatif lebih cepat dibandingkan dengan yang tidak diberi pupuk (Tabel 3). Hasil penelitian Munir dan Ariffin (2010) menunjukkan bahwa penambahan kompos mampu menyumbangkan hara seperti nitrogen, fosfor, kalium dan unsur mikro lainnya sehingga keseimbangan hara untuk munculnya bunga lebih cepat, dimana unsur hara $\mathrm{P}$ mempunyai peranan mempercepat pembentukkan bunga, pemasakan buah dan biji.

Berdasarkan Tabel 3 menunjukkan bahwa pemberian masing-masing jenis 
kompos (jerami padi dan TKKS) yang ditambahkan dengan pupuk NPK $250 \mathrm{~kg} \mathrm{ha}^{-1}$ mampu mempercepat umur panen tanaman cabai, berbeda nyata dengan perlakuan tanpa kompos dan pupuk NPK pada berbagai dosis perlakuan, namun tidak berbeda nyata dengan kombinasi perlakuan lainnya. Jumin (2012) menyatakan bahwa pemberian bahan organik ke dalam tanah dapat memperbesar ketersediaan fosfor dan juga dapat menciptakan kondisi tanah sehingga ketersediaan fosfor meningkat. Hasil penelitian Dewanto et al. (2013), pemberian pupuk organik dapat memperbaiki sifat-sifat tanah seperti sifat fisik, kimia dan biologi tanah. Bahan organik merupakan perekat butiran lepas, sumber hara tanaman dan sumber energi dari sebagian besar organisme tanah.

\section{Hasil Analisis Statistik dan Produksi Tanaman Cabai yang Diberi Kompos dan Pupuk NPK}

Hasil analisis statistik produksi tanaman cabai yang diberi kompos dan pupuk NPK dapat dilihat pada Tabel 4. Tabel 4 menunjukkan bahwa pemberian kompos, pemberian pupuk NPK, serta pemberian kombinasi kompos dan pupuk NPK tidak berpengaruh nyata terhadap panjang buah, jumlah buah per tanaman, bobot buah per tanaman, dan bobot buah per $\mathrm{m}^{2}$. Peningkatan produksi dan produktivitas tanaman cabai dapat dilihat pada Tabel 5.

Tabel 4. Hasil analisis statistik komponen produksi dan produktivitas tanaman cabai

\begin{tabular}{lcccc}
\hline Perlakuan & $\begin{array}{c}\text { Panjang } \\
\text { Buah }\end{array}$ & $\begin{array}{c}\text { Jumlah Buah } \\
\text { per Tanaman }\end{array}$ & $\begin{array}{c}\text { Bobot Buah per } \\
\text { Tanaman }\end{array}$ & $\begin{array}{c}\text { Bobot Buah per } \\
\text { Meter Persegi }\end{array}$ \\
\hline Kompos & & & & \\
$\quad$ F. hitung & $1.78^{\mathrm{ns}}$ & $1.32^{\mathrm{ns}}$ & $1.70^{\mathrm{ns}}$ & $2.17^{\mathrm{ns}}$ \\
$\quad$ F.tabel & 3.63 & 3.63 & 3.63 & 3.63 \\
NPK & & & & \\
$\quad$ F. hitung & $0.76^{\mathrm{ns}}$ & $0.89^{\mathrm{ns}}$ & $1.57^{\mathrm{ns}}$ & $3.25^{\mathrm{ns}}$ \\
$\quad$ F. tabel & 3.63 & 3.63 & 3.63 & 3.63 \\
Kompos* NPK & & & & \\
$\quad$ F. hitung & $0.06^{\mathrm{ns}}$ & $0.16^{\mathrm{ns}}$ & $0.19^{\mathrm{ns}}$ & $0.32^{\mathrm{ns}}$ \\
$\quad$ F. tabel & 3.01 & 3.01 & 3.01 & 3.01 \\
\hline
\end{tabular}

Keterangan: *= nyata; ns=tidak nyata

Tabel 5. Produksi dan produktivitas tanaman cabai yang diberi kompos dan NPK

\begin{tabular}{lcrrc}
\hline \multicolumn{1}{c}{ Perlakuan } & $\begin{array}{c}\text { Panjang } \\
\text { Buah }\end{array}$ & $\begin{array}{c}\text { Jumlah } \\
\text { Buah per } \\
\text { Tanaman }\end{array}$ & $\begin{array}{c}\text { Bobot } \\
\text { Buah per } \\
\text { Tanaman }\end{array}$ & $\begin{array}{c}\text { Bobot } \\
\text { Buah per } \\
\text { Meter Persegi }\end{array}$ \\
\hline Tanpa kompos + NPK 0 kg ha-1 & $16.38 \mathrm{a}$ & $82.40 \mathrm{a}$ & $384.50 \mathrm{a}$ & $1022.1 \mathrm{~b}$ \\
Tanpa kompos + NPK 125 kg ha-1 & $16.45 \mathrm{a}$ & $87.80 \mathrm{a}$ & $407.67 \mathrm{a}$ & $1062.7 \mathrm{ab}$ \\
Tanpa kompos + NPK 250 kg ha-1 & $16.65 \mathrm{a}$ & $87.93 \mathrm{a}$ & $423.52 \mathrm{a}$ & $1232.7 \mathrm{ab}$ \\
Kompos TKKS + NPK 0 kg ha-1 & $16.42 \mathrm{a}$ & $92.40 \mathrm{a}$ & $445.73 \mathrm{a}$ & $1199.0 \mathrm{ab}$ \\
Kompos TKKS + NPK 125 kg ha-1 & $16.48 \mathrm{a}$ & $92.53 \mathrm{a}$ & $438.99 \mathrm{a}$ & $1234.4 \mathrm{ab}$ \\
Kompos TKKS + NPK 250 kg ha-1 & $16.70 \mathrm{a}$ & $108.80 \mathrm{a}$ & $539.66 \mathrm{a}$ & $1367.1 \mathrm{ab}$ \\
Kompos Jerami + NPK 0 kg ha-1 & $16.75 \mathrm{a}$ & $93.20 \mathrm{a}$ & $439.49 \mathrm{a}$ & $1090.3 \mathrm{ab}$ \\
Kompos Jerami + NPK 125 kg ha-1 & $16.83 \mathrm{a}$ & $102.87 \mathrm{a}$ & $490.67 \mathrm{a}$ & $1339.4 \mathrm{ab}$ \\
Kompos Jerami + NPK 250 kg ha-1 & $16.87 \mathrm{a}$ & $112.73 \mathrm{a}$ & $560.76 \mathrm{a}$ & $1480.2 \mathrm{a}$ \\
\hline Kera
\end{tabular}

Keterangan: Angka-angka yang diikuti oleh huruf kecil pada baris yang sama menunjukkan tidak berbeda nyata menurut uji jarak berganda Duncan pada taraf $5 \%$. 
Tabel 5 menunjukkan bahwa kombinasi pemberian kompos dan pupuk NPK, kompos dan pupuk NPK saja tidak berbeda nyata terhadap panjang buah tanaman cabai yang cenderung sama. Hasil penelitian Nurlenawati et al. (2010), panjang buah lebih dipengaruhi oleh faktor genetik dibandingkan faktor lingkungan, walaupun demikian tetap menunjukkan bahwa kombinasi dari kedua jenis pupuk yaitu pupuk anorganik dan organik dapat meningkatkan panjang buah tanaman cabai.

Berdasarkan data hasil penelitian pada Tabel 5 menunjukkan bahwa pemberian kompos dan peningkatan dosis pupuk NPK menghasilkan jumlah buah per tanaman cabai yang tidak berbeda nyata antar perlakuan, namun cenderung mengalami peningkatan. Pemberian kompos jerami padi dan pupuk NPK $250 \mathrm{~kg} \mathrm{ha}^{-1}$ jumlah buah per tanaman cabai (112.73 buah) lebih banyak dibandingkan dengan perlakuan lainnya, jika dibandingkan dengan tanpa kompos dan pupuk NPK $250 \mathrm{~kg} \mathrm{ha}^{-1}$ peningkatannya sebanyak 24.80 buah $(28.20 \%)$.

Pemberian kompos dan peningkatan dosis pupuk NPK tidak berbeda nyata terhadap bobot buah per tanaman pada tanaman cabai, namun cenderung mengalami peningkatan (Tabel 5). Hasil penelitian Kholidin et al. (2016) menunjukkan bahwa pemberian pupuk kandang dan tambahan pupuk anorganik NPK tanpa pemberian mulsa cenderung meningkatkan berat segar total per tanaman pada tanaman sawi yaitu $173.88 \mathrm{~g}$.

Bobot buah per $\mathrm{m}^{2}$ tanaman cabai cenderung meningkat dengan pemberian kompos jerami padi dan pupuk NPK $250 \mathrm{~kg}$ $\mathrm{ha}^{-1}$, berbeda nyata dengan perlakuan tanpa kompos dan pupuk NPK $0 \mathrm{~kg} \mathrm{ha}^{-1}$, namun tidak berbeda nyata dengan kombinasi perlakuan lainnya (Tabel 5). Hal ini sejalan dengan hasil penelitian Ariani (2009), semakin tinggi dosis pupuk NPK yang diberikan pada berbagai mulsa, maka jumlah buah cabai per tanaman dan berat buah per tanaman juga semakin meningkat.

Pemberian kompos TKKS maupun kompos jerami padi dapat meningkatkan berat buah per $\mathrm{m}^{2}$ dengan atau tanpa pupuk NPK. Pemberian kompos jerami padi dan pupuk NPK $125 \mathrm{~kg} \mathrm{ha}^{-1}$ cenderung meningkatkan berat buah per $\mathrm{m}^{2}$ sebesar $22.85 \%$ dibandingkan dengan pemberian kompos jerami padi dan pupuk NPK $0 \mathrm{~kg} \mathrm{ha}^{-1}$. Pemberian kompos TKKS dan pupuk
NPK $125 \mathrm{~kg} \mathrm{ha}^{-1}$ cenderung meningkatkan berat buah per $\mathrm{m} 2$ sebesar $2.95 \%$ dibandingkan dengan pemberian kompos TKKS dan pupuk NPK $0 \mathrm{~kg} \mathrm{ha}^{-1}$. Hal ini menunjukkan bahwa pada pemberian kompos jerami padi dan pupuk NPK $125 \mathrm{~kg} \mathrm{ha}^{-1}$ sudah mampu meningkatkan berat buah per $\mathrm{m}^{2}$, sehingga dengan pemberian kompos jerami padi dan pupuk NPK $125 \mathrm{~kg} \mathrm{ha}^{-1}$ dapat mengurangi penggunaan pupuk NPK.

\section{KESIMPULAN}

Pemberian kompos jerami padi mampu meningkatkan tinggi tanaman, tinggi dikotomus, lebar tajuk, mempercepat umur berbunga dan umur panen serta meningkatkan bobot buah per $\mathrm{m}^{2}$ tanaman cabai. Pemberian kompos TKKS mampu meningkatkan tinggi tanaman, lebar tajuk, mempercepat umur berbunga dan umur panen, tinggi dikotomus, lebar tajuk, mempercepat umur berbunga dan umur panen. Pemberian kompos jerami padi (5 ton $\left.\mathrm{ha}^{-1}\right)$ dan pupuk NPK $125 \mathrm{~kg} \mathrm{ha}^{-1}(1 / 2$ dosis anjuran) cenderung meningkatkan bobot buah per $\mathrm{m}^{2}$ pada tanaman cabai.

\section{DAFTAR PUSTAKA}

Antil, R.S., A. Bar-Tal, P. Fine, A. Hadas. 2011. Predicting nitrogen and carbon mineralization of composted manure and sewage sludge in soil. Compost Sci Util. 19(1): 33-43.

Ariani, E. 2009. Uji pupuk NPK 16:16:16 dan berbagai jenis mulsa terhadap hasil tanaman cabai (Capsicum annuum L). Jurnal Sagu. 8(1): 5-9.

Arifiati, A., Syekhfani, Y. Nuraini. 2017. Uji efektivitas perbandingan bahan kompos paitan (Tithonia diversifolia), tumbuhan paku (Dryopteris filixmas) dan kotoran kambing terhadap serapan $\mathrm{N}$ tanaman jagung pada Inceptisol. Jurnal Tanah dan Sumberdaya Lahan. 4(2): 543-552.

[BPS] Badan Pusat Statistik. 2015. Data Produksi Cabai Provinsi Riau. www.bps.go.id/getfile.php?news.html. [18 November 2016]. 
Dewanto, F.G., J.J.M.F. Londok, R.A.F. Tuturoong, W.B. Kaunang. 2013. Pengaruh pemukan anorganik dan organik terhadap produksi tanaman jagung sebagai sumber pakan. Jurnal Zootek. 32(5): 1-8.

Dhani, H. 2013. Pengaruh Pupuk Vermikompos pada Tanah Inceptisol terhadap Pertumbuhan dan Hasil Sawi Hijau (Brassica juncea L.). [Skripsi] (Tidak dipublikasikan). Universitas Riau. Pekanbaru.

Hapsoh, Gusmawartati, A.I. Amri, A. Diansyah. 2017. Respon pertumbuhan dan produksi tanaman cabai keriting (Capsicum annuum L.) terhadap aplikasi pupuk kompos dan pupuk anorganik di polibag. J. Hort. Indonesia. 8(3): 203-208.

Hardjowigeno, S. 2007. Ilmu Tanah. Akademika Pressindo. Jakarta.

Jumin, H.B. 2012. Dasar-Dasar Agronomi. PT Rajagrafindo Persada. Jakarta.

Kholidin, M., A. Rauf, H.N. Barus. 2016. Respon pertumbuhan dan hasil tanaman sawi (Brassica juncea L.) terhadap kombinasi pupuk organik, anorganik dan mulsa di Lembah Palu. J. Agrotekbis. 4(1): 1-7.
Munir, R., Y. Arifin. 2010. Pertumbuhan dan hasil mentimun akibat pemberian pupuk kandang ayam dan gandasil B. Jurnal Jerami. 3(2): 63-70.

Nurlenawati, N., A. Jannah, Nimih. 2010. Respon pertumbuhan dan hasil tanaman cabai merah (Capsicum annuum L.) Varietas Prabu terhadap berbagai dosis pupuk fosfat dan bokashi jerami limbah jamur merang. J. Agrika. 4(1): 9-20.

Prasetya, M. E. 2014. Pengaruh pupuk NPK mutiara dan pupuk kandang sapi terhadap pertumbuhan dan hasil tanaman cabai merah keriting varietas arimbi (Capsicum annuum L.). Jurnal Agrifor. 8(2): 191-198.

Subhan, N. Nurtika, N. Gunadi. 2009. Respons tanaman tomat terhadap penggunaan pupuk majemuk NPK 15-15-15 pada tanah latosol pada musim kemarau. J. Hort. 19(1): 40-48.

Sugestiadi, H., Nurbaiti, Deviona. 2014. Pemilihan kriteria seleksi untuk perakitan cabai di lahan gambut. Jurnal Online Mahasiswa Fakultas Pertanian Universitas Riau. 1(1): 1-11.

Yusuf, M. 2014. Pengujian Kombinasi Bahan Baku Kompos (Basah) dari Sampah Kota Organik dan Limbah Pertanian terhadap Mutu Kompos. [Skripsi] (Tidak dipublikasikan). Universitas Riau. Pekanbaru. 59 hal. 